\title{
Achievement of Quality Education of Primary School Students: A Micro Level Study At Kalyani Community Block in West Bengal
}

\author{
Mukhlesur Rahaman Gain, Subrata Biswas and Prasenjit Deb \\ Dept. of Lifelong Learning \& Extension, University of Kalyani, Kalyani, West Bengal, India \\ Corresponding author email: mukhlesurlle21@klyuniv.ac.in
}

\begin{abstract}
Education is indispensable in order to elevate the standard of life. Education makes an individual a better person, because it broadens one's exposure to the world or teaches one to distinguish between right and wrong. Primary school is the first step in a child's education. Hence, it is often called 'basic education'. For once the quality of primary education is adequate; students may have better education in higher levels. So it may also be called an 'entrance to higher education'. The quality of education at primary level in West Bengal is far from satisfactory. In government schools of West Bengal students are provided Mid-day Meal for much required nutrition along with education. They are also provided with books, exercise books, school dresses, school bags, scholarships and other basic amenities. The present study attempts to find out why the quality of students in government schools still lower than that of the private schools.
\end{abstract}

KEY WORDS: QUALITY EDUCATION, STUDENTS, TEACHERS, PARENTS, MID-DAY MEAL, GOVERNMENT SCHOOL AND PRIVATE SCHOOL.

\section{INTRODUCTION}

Fredrick Douglass said "It is easier to build stronger children than to repair broken men". Education is the first step in the edifice of character building and it also includes development of social, cognitive, cultural, emotional and physical skills. During a survey, some researchers asked a lady - why she considers it necessary for her daughter to attend school. The lady simply answered "just to live a safe life - we are farmers, and there are bottles of pesticides in our house, if she can read, she will never mistake it to be anything else". The so called uneducated mother may not have any idea what she was saying, but it clearly shows how intensely she wanted her daughter to attend school and get education. There is a saying in rural West Bengal which goes something like "wealth can

Biosc Biotech Res Comm P-ISSN: 0974-6455 E-ISSN: 2321-4007

\section{rossef}

Identifiers and Pagination

Year: 2021 Vol: 14 No (5) Special Issue

Pages: 231-241

This is an open access article under Creative

Commons License Attribn 4.0 Intl (CC-BY). DOI: http://dx.doi.org/10.21786/bbrc/14.5/25 be divided but not education'. Primary school is the first step in a child's education. Hence, primary education is often called 'basic education'. For once the quality of primary education is adequate; students may have better education in higher levels. So it may also be called an 'entrance to higher education'. The quality of education at primary level in West Bengal is far from satisfactory.

Although a report of Annual State Education Report (ASER) for 2015-16 shows little progress but that does not keep up much hope. It is only because in some schools some teachers have been trying at their own level best to make their students learned. They do not merely see themselves as teachers but as researchers, trying to find out novel ways to teach their students effectively rather than sticking to traditional methods. It is found that where there is a communication gap between parents and teachers the quality of education is relatively lower vis-à-vis where there is a contact among parents and teachers on a regular basis. In order to bring about a comprehensive development, there is a requisite of routine communication among parents and teachers on the one hand and a systematic upgradation of the present education system on the other. The school can
Article Information

Received: $17^{\text {th }}$ Jan 2021 Accepted after revision: $30^{\text {th }}$ Mar 2021 
also influence the parents' involvement by notifying the parents of their child's progress. It is clear that the more the school notifies the parents about the meetings and activities that need to be attended by parents at school, the higher is the parental involvement, seen in discussing their child's activities in school, helping their child with school homework and guiding their child in their preparation for school examinations.

Broadly two types of schools are prevalent there in West Bengal viz. government schools and private schools. The government schools are under the School Education Department and Panchayat and Rural Development Department (Shishu Shiksha Kendra). Private schools are either affiliated to West Bengal Board of Primary Education or central education boards. In government schools of West Bengal students are provided Mid-day Meal for required nutrition alongwith education. They are also provided with books, exercise books, school dresses, school bags, scholarships and other basic amenities. Due to lack of knowledge, adequate time and poverty, the guardians of government school children remain busy gaining livelihood. Therefore they are unable to assist their children in enhancing quality education. The parents of the private school goers are relatively much more educated and financially stable, so they are able to help their children with money and knowledge. Children's education is of utmost priority to these parents. In private schools the Pupil to Teachers Ratio is also adequate.

Ahmad Susanto (2019) shows that there was a significant effect of parental guidance and emotional intelligence together on students' learning achievement in social science. Parental guidance and emotional intelligence contributed $64.2 \%$ to the students' learning achievement in social science and as a result, there was a significant effect of parental guidance on students' learning achievement in social sciences. This is evidenced by the acquisition of sig $=0.037<0.05$ and $t$ count $=2.114 ; 3$ ) There is a significant effect of emotional intelligence on learning achievement in social sciences. This is revealed by the $\mathrm{p}<0.05$ and $\mathrm{t}$-count of 6.336 .

According to Lamar University online document (2019), it was found that firstly, less than 60 percent of students in no-degree families completed their degree, compared with 70 percent of students in one- and two-degree families. The study found 86 percent of children with parents who have less than a high school degree live in low-income families, compared with 67 percent of children with parents who have a high school degree (but no college education) and 31 percent of children with at least one parent who has some college education. The study found low socioeconomic status, in turn, can affect family interactions and lead to behavioural problems that can impact children's academic and intellectual development. In addition, parents who put great effort financially tends to have children who are more cynical about their education and job prospects.

The study of Abie Ntekane (2018) found that the participation of family in learning helps to improve students' performance, reduce non-attendance and restore parents' self-assurance in their children's education. Learners with parents or caregivers, who are involved in learners' education, earn higher grades and test scores, had improved social skills and show improved behaviour. The paper also offered a perception that something that overall community and the world at large are in need of, as it would highly contribute in reducing crime and poverty. Ideally it would help to have a greater percentage of parental involvement in their children's education. Parental involvement is associated with a wide range of positive child outcomes in primary and high schools, such as good academic skills, positive attitudes and social competence. Parental involvement in learning acts as a gel that helps to make learning for children pleasant and encourages them to work even more as they seek to make those closest to them proud.

The study of Tyler Bailey (2017) shows that the four areas of speculation were recognized in the research including - responsibility, driving force, communication, and students' relationship with teachers and parents. These identified areas formed a well-rounded point of view on student success and how parents played a role in that achievement. Ultimately, the personal accounts imparted by the students, teachers, and prospectus coach provided valuable perspectives into their educational experiences and viewpoints and formed relevant insights to be reviewed by teachers, parents, and school community.

The study of Asadul Islam (2017), shows that the full effect of such programs takes some time to be visible and to become a significant factor. In the short term, better performing students (those with baseline test scores in the top third) benefitted more from the program; but over time, as the meetings progressed, gradually the low-performing students too began to benefit. There were also positive pills over effects in the treatment of schools among students in classes that were not in the part of the intervention. The effect of the treatment is stable and robust, and observed regardless of education level and experience of the teachers, or the socioeconomic backgrounds of the students. We observed some parents needed a nudge to motivate them to meet with teachers. We found parents and other household members spending more time at home helping children to do home work or study. The intervention led to significant improvement in the attitudes, behavior, and confidence of children.

Thus our findings extend the existing literature and confirm that the positive effect of parents' involvement on students' learning observed in developed countries can also hold true in low-income countries. Educational outcomes of children in developing countries such as Bangladesh can be significantly improved through programs that stimulate greater parent-teacher interaction and encourage parents to be more involved in their children's studies. Such programs have immense potential for scaling up because they are low-cost and easy to implement, even in disadvantaged communities where parents have low levels of literacy. The result of the study of Yuddin Passiri (2017) reveals that there was 
a positive and significant influence of parental education level on the learning accomplishment shown by the partial fortitude test obtained by the input value of 7.5\%. The data also showed a positive influence and significant level of income on learning attainment which is shown by partial determination test obtained by input value of $17.9 \%$. Further the testing result also revealed a positive and considerable influence of education level and income level on learning accomplishment which is indicated by simultaneous determination test obtained by contribution value of $3.47 \%$ and the rest $96.53 \%$ influenced by other factors not included in research variable.

The study of Anupama Mishra (2016) found that these mothers were regularly involved in ongoing learning activities at school and at home. Their involvement is grounded on regular observation rather than ambitious long term planning. They were aware of child's school life and provided necessary support and sought help, if needed. The overall resultant of the study of Paula Johnson (Marozas), (2016) indicates that the parents can influence positive student attitudes the most. The most interesting is that even when parents were not directly involved in the learning process for their child, they can still have an encouraging impact by discussing the significance of math learning. According to the study when parents stressed the importance of learning math to their children, it would positively impact the student's future achievement in math. When students really believed that exercising math will directly benefit them in their real lives, they will have better attitudes toward learning. Their self-efficacy would improve when they kept trying, and then math achievement will improve because they were more confident in themselves.

The study of Jai Parkash and Sushma Rani (2016) shows that, there is a significant relationship between academic achievements of students and parental involvement of Private and Government School students. Lack of parental involvement in Government Schools is the reason that the academic achievement level of students is also low. There is significant difference in the academic achievements of students of Private and Government Schools. It may happen that students of private schools develop in a better way because they have better facilities to achieve higher standards. Also, there is significant difference in parental involvement of Private and Government School students. Parents belonging to Government Schools' communities have less parental involvement in comparison to parents who are in Private areas. The study of Camelia Voicu, Alina Anghel, Maria Savu-Cristescu (2015) has revealed that not only socioeconomic factors are important in conditioning parents' attitudes and behaviors towards children's rights, but also parents' awareness and understanding of these rights. Consequently, parental education programs will focus on increasing the understanding and awareness of children's rights, promotion of pro-democratic cultural patterns and learning new ways to manage the problems of intra-familial relationships.

The results of the study Charo Reparaz, Maria Angeles
Sotes-Elizalde (2015) show the great efforts made in the schools to involve parents, according to the principals interviewed. The parents have a more moderate evaluation in this respect. Regarding performance in science, it is found in Spain and in Germany that not all factors related to parental participation favor a higher achievement.

The study of Gina A. N. Chowa, Rainier D. Masa, Jenna Tucker(2013) shows parental involvement at home and in school are meaningfully different in constructing the population of Ghanaian youth and their parents and parental involvement predicts academic performance. Results suggest that parental involvement is a biodimensional construct consisting of home and school involvement. The effect of parental involvement on youth's academic performance appears to be a function of the type of involvement. Home based parental involvement is associated positively with academic performance, while school-based parental involvement has a negative association. Parents can model positive attitudes and behaviour toward school and convey the importance of school. According to a study of Drèze and Kingdon, 2001, enrolment increases when the benefits of attending school outweigh the costs. Sending a child to school involves direct costs (such as uniform, text books, tuition fee etc.) and opportunity costs (such as child's forgone earnings and parents' time and effort required to drop and pick up their child from school).

Statement of the Problems: The main issue of the present study is to find out why the quality of education of government school students is lower vis-à-vis private school students. The quality of Mid-day Meal provided is not good because government allotment for it is a meager Rs. 4.48 per student. To improve the quality of food it is essential on part of the government to sufficiently increase the allotment. It has been found out that wherever the quality of education is superior it is because of the involvement of the parents along with teachers. But most parents of government school students are either illiterate or even if literate then of inadequate nature and hence they are unable to assist their children in their study. Should the government take adequate steps in order to resolve this problem? or, can this problem be left as it presently is?

Significance of the study: The present study will enable us to understand the role of parents as well as private tutors for the quality education of their children at primary level. Teachers will have clearer perceptions about their students.

\section{Objectives}

- To study the achievement of quality education of primary school students.

- To study the role of teachers in enhancing quality education of primary school students.

- To study the role of parents in enhancing quality education of primary school students.

- To study the relationship between parents and teachers for enhancing quality education of primary 
school students.

- To study the quality of Mid-day Meal in primary schools of Kalyani Community Development Block of West Bengal.

\begin{tabular}{|c|c|c|}
\hline Variable & Mean & Std Dev \\
\hline Type of School $\left(\mathrm{X}_{1}\right)$ & 1.32 & 0.58 \\
\hline Religion $\left(\mathrm{X}_{2}\right)$ & 1.20 & 0.45 \\
\hline Social Identity $\left(\mathrm{X}_{3}\right)$ & 2.06 & 1.00 \\
\hline Lesser Financial Stability $\left(\mathrm{X}_{4}\right)$ & 3.76 & 1.74 \\
\hline Gender $\left(\mathrm{X}_{5}\right)$ & 1.50 & 0.50 \\
\hline Class $\left(\mathrm{X}_{6}\right)$ & 1.50 & 0.50 \\
\hline $\begin{array}{l}\text { Who accompanies you to school? }\left(\mathrm{X}_{7}\right) \\
\text { Who accompanies you while returning- }\end{array}$ & 3.87 & 1.35 \\
\hline from school? $\left(\mathrm{X}_{8}\right)$ & 3.95 & 1.32 \\
\hline Solo(Alone) $\left(\mathrm{X}_{9}\right)$ & 75.90 & 62.88 \\
\hline Under Someone $\left(\mathrm{X}_{10}\right)$ & 18.90 & 42.99 \\
\hline At $\operatorname{school}\left(\mathrm{X}_{11}\right)$ & 217.80 & 73.19 \\
\hline Most preferred cause(s) in school $\left(\mathrm{X}_{12}\right)$ & 2.26 & 0.79 \\
\hline Can you read? $\left(\mathrm{X}_{13}\right)$ & 2.42 & 0.74 \\
\hline $\begin{array}{l}\text { Can you write? }\left(\mathrm{X}_{14}\right) \\
\text { Problem in understanding text in }\end{array}$ & 2.46 & 0.70 \\
\hline $\begin{array}{l}\text { school }\left(\mathrm{X}_{15}\right) \\
\text { Why do you face problem in under- }\end{array}$ & 2.45 & 0.54 \\
\hline $\begin{array}{l}\text { standing text in school? }\left(\mathrm{X}_{16}\right) \\
\text { Do you refer to your teacher if you- }\end{array}$ & 54.07 & 47.96 \\
\hline $\begin{array}{l}\text { face problem? }\left(\mathrm{X}_{17}\right) \\
\text { Do the teachers teach carefully- }\end{array}$ & 1.33 & 0.80 \\
\hline (affectionately)? $\left(\mathrm{X}_{17}\right)$ & 1.79 & 0.41 \\
\hline $\begin{array}{l}\text { Do the teachers Punish? }\left(\mathrm{X}_{19}\right) \\
\text { How much do you spend on- }\end{array}$ & 3.54 & 0.99 \\
\hline your tuition? $\left(\mathrm{X}_{20}\right)$ & 303.64 & 214.09 \\
\hline $\begin{array}{l}\text { Do you receive Mid-day Meal? }\left(\mathrm{X}_{21}\right) \\
\text { Do you receive sufficient Meal- }\end{array}$ & 1.71 & 0.46 \\
\hline $\begin{array}{l}\text { (Mid-day Meal)? }\left(\mathrm{X}_{22}\right) \\
\text { How is the quality of the Meal- }\end{array}$ & 30.07 & 44.28 \\
\hline $\begin{array}{l}\text { (Mid-day Meal)? }\left(\mathrm{X}_{23}\right) \\
\text { Do you wash your hands before- }\end{array}$ & 28.13 & 43.32 \\
\hline eating? $\left(\mathrm{X}_{24}\right)$ & 30.81 & 43.80 \\
\hline Does your school have toilet? $\left(\mathrm{X}_{25}\right)$ & 2.69 & 0.54 \\
\hline $\begin{array}{l}\text { Does anybody recite you stories? }\left(\mathrm{X}_{26}\right) \\
\text { The perception level of students on- }\end{array}$ & 1.48 & 0.50 \\
\hline quality education at primary level (Y) & 20.23 & 3.01 \\
\hline
\end{tabular}

Scope of the Study: The scope of the present study is to measure the role of parents as well as teachers in their children's education at primary level at Kalyani of Nadia district.

\section{METHODS}

Survey-based descriptive research method is followed.

Study area: The present study has been conducted in the primary schools of Kalyani Community Development 
Block in Nadia District of West Bengal.

Sources of Data: The primary data was mainly collected from the target primary school students of different Government and Private Schools at Kalyani Community Development block of Nadia District of West Bengal.

Population: All the primary students of seven Gram Panchayats of Kalyani Community Development block in Nadia District of West Bengal constitute the population.

Sample: A random sample of 100 primary school students was identified from Seven Gram Panchayates of Kalyani Community Development Block in Nadia District of West Bengal.

Tool: A scheduled questionnaire was prepared to study the achievement level of primary school students and another one to study the perceptional view from the target primary school students. The survey was conducted during December, 2020 to Jan, 2021. Statistical methods as SPSS 2.0 version to explore the target with the help of correlation, regression, step-down regression, Multiple Regression Analysis and Chi-Square test have been used.

\begin{tabular}{|c|c|c|}
\hline Variables & Chi-Square & Significance \\
\hline Type of School (X $)$ & 77.3600 & 0.0000 \\
\hline Religion $\left(\mathrm{X}_{2}\right)$ & 109.5200 & 0.0000 \\
\hline Social Identity $\left(\mathrm{X}_{3}\right)$ & 51.7600 & 0.0000 \\
\hline Lesser Financial Stability $\left(\mathrm{X}_{4}\right)$ & 83.3600 & 0.0000 \\
\hline Gender $\left(\mathrm{X}_{5}\right)$ & 0.0000 & 1.0000 \\
\hline $\operatorname{Class}\left(\mathrm{X}_{6}\right)$ & 0000 & 1.0000 \\
\hline $\begin{array}{l}\text { Who accompanies you to school? }\left(\mathrm{X}_{7}\right) \\
\text { Who accompanies you while returning- }\end{array}$ & 77.4800 & 0.0000 \\
\hline from school? $\left(\mathrm{X}_{8}\right)$ & 84.9200 & 0.0000 \\
\hline Solo(Alone) $\left(\mathrm{X}_{9}\right)$ & 96.9600 & 0.0000 \\
\hline Under Someone $\left(\mathrm{X}_{10}\right)$ & 291.2000 & 0.0000 \\
\hline At $\operatorname{school}\left(\mathrm{X}_{11}\right)$ & 230.2600 & 0.0000 \\
\hline Most preferred cause(s) in $\operatorname{school}\left(\mathrm{X}_{12}\right)$ & 65.2000 & 0.0000 \\
\hline Can you read? $\left(\mathrm{X}_{13}\right)$ & 27.7400 & 0.0000 \\
\hline Can you write? $\left(\mathrm{X}_{14}\right)$ & 32.2400 & 0.0000 \\
\hline $\begin{array}{l}\text { Problem in understanding text in- school }\left(\mathrm{X}_{15}\right) \\
\text { Why do you face problem in under- }\end{array}$ & 44.4200 & 0.0000 \\
\hline $\begin{array}{l}\text { standing text in school? }\left(\mathrm{X}_{16}\right) \\
\text { Do you refer to your teacher if you face- }\end{array}$ & 95.8000 & 0.0000 \\
\hline $\begin{array}{l}\text { problem? }\left(\mathrm{X}_{17}\right) \\
\text { Do the teachers teach carefully- }\end{array}$ & 121.3400 & 0.0000 \\
\hline (affectionately)? $\left(\mathrm{X}_{18}\right)$ & 33.6400 & 0.0000 \\
\hline $\begin{array}{l}\text { Do the teachers Punish? }\left(\mathrm{X}_{19}\right) \\
\text { How much do you spend on your- }\end{array}$ & 35.0400 & 0.0000 \\
\hline tuition? $\left(\mathrm{X}_{20}\right)$ & 60.4200 & 0.0000 \\
\hline $\begin{array}{l}\text { Do you receive Mid-day Meal? }\left(\mathrm{X}_{21}\right) \\
\text { Do you receive sufficient Meal- }\end{array}$ & 17.6400 & 0.0000 \\
\hline $\begin{array}{l}\text { (Mid-day Meal)? }\left(\mathrm{X}_{22}\right) \\
\text { How is the quality of the Meal- }\end{array}$ & 53.0600 & 0.0000 \\
\hline $\begin{array}{l}\text { Mid-day Meal)? }\left(\mathrm{X}_{23}\right) \\
\text { Do you wash your hands before- }\end{array}$ & 27.2000 & 0.0000 \\
\hline eating? $\left(\mathrm{X}_{24}\right)$ & 108.5600 & 0.0000 \\
\hline Does your school have toilet? $\left(\mathrm{X}_{25}\right)$ & 113.5200 & 0.0000 \\
\hline Does anybody recite you stories? $\left(\mathrm{X}_{26}\right)$ & 0.1600 & 0.6892 \\
\hline
\end{tabular}


Variable: The following variables are used in this study:

Dependent Variable: The perception level of students on quality education at primary level (Y)

Independent Variable: Type of School $\left(\mathrm{X}_{1}\right)$, Religion $\left(\mathrm{X}_{2}\right)$, Social Identity $\left(\mathrm{X}_{3}\right)$, Lesser Financial Stability $\left(\mathrm{X}_{4}\right)$, Gende $\mathrm{r}\left(\mathrm{X}_{5}\right)$, Class $\left(\mathrm{X}_{6}\right)$, Who accompanies you to school? (X7), Who accompanies you while returning from school? $\left(\mathrm{X}_{8}\right)$, Solo (Alone) $\left(\mathrm{X}_{9}\right)$, Under Someone $\left(\mathrm{X}_{10}\right)$, At school $\left(\mathrm{X}_{11}\right)$, Most preferred cause(s) in school $\left(\mathrm{X}_{12}\right)$, Can you read?
$\left(\mathrm{X}_{13}\right)$, Can you write? $\left(\mathrm{X}_{14}\right)$, Problem in understanding text in school $\left(\mathrm{X}_{15}\right)$, Why do you face problem in understanding text in school? $\left(\mathrm{X}_{16}\right)$, Do you refer to your teacher if you face problem? $\left(\mathrm{X}_{17}\right)$, Do the teachers teach carefully (affectionately)? $\left(\mathrm{X}_{18}\right)$, Do the teachers Punish? $\left(\mathrm{X}_{19}\right)$, How much do you spend on your tuition? (X20), Do you receive Mid-day Meal? $\left(\mathrm{X}_{21}\right)$, Do you receive sufficient Meal (Mid-day Meal)? $\left(\mathrm{X}_{22}\right)$, How is the quality of the Meal (Mid-day Meal)? $\left(\mathrm{X}_{23}\right)$, Do you wash your hands before eating? $\left(\mathrm{X}_{24}\right)$, Does your school have toilet? $\left(\mathrm{X}_{25}\right)$, Does anybody recite you stories? $\left(\mathrm{X}_{26}\right)$.

Table 3. Correlation analysis between dependent variable the perception level of students on quality education at primary level $(\mathrm{Y})$ and 26 casual variables.

\begin{tabular}{|c|c|}
\hline Variables & r' Values \\
\hline Type of School $\left(\mathrm{X}_{1}\right)$ & $-0.4726^{* *}$ \\
\hline Religion $\left(\mathrm{X}_{2}\right)$ & $0.2415^{*}$ \\
\hline Social Identity $\left(\mathrm{X}_{3}\right)$ & 0.1590 \\
\hline Lesser Financial Stability $\left(\mathrm{X}_{4}\right)$ & $-0.2519^{*}$ \\
\hline Gender $\left(\mathrm{X}_{5}\right)$ & 0.0633 \\
\hline $\operatorname{Class}\left(\mathrm{X}_{6}\right)$ & 0.0967 \\
\hline Who accompanies you to school? $\left(\mathrm{X}_{7}\right)$ & 0.1906 \\
\hline Who accompanies you while returning from school? $\left(\mathrm{X}_{8}\right)$ & 0.1323 \\
\hline Solo (Alone) $\left(X_{9}\right)$ & -0.1570 \\
\hline Under Someone $\left(\mathrm{X}_{10}\right)$ & -0.1181 \\
\hline At school $\left(\mathrm{X}_{11}\right)$ & 0.1209 \\
\hline Most preferred cause(s) in school $\left(\mathrm{X}_{11}\right)$ & 0.1492 \\
\hline Can you read? $\left(\mathrm{X}_{13}\right)$ & -0.1025 \\
\hline Can you write? $\left(\mathrm{X}_{14}\right)$ & -0.1268 \\
\hline $\begin{array}{l}\text { Problem in understanding text in School }\left(\mathrm{X}_{15}\right) \\
\text { Why do you face problem in }\end{array}$ & $0.3709^{* *}$ \\
\hline understanding text in school? $\left(\mathrm{X}_{16}\right)$ & $-0.3818^{* *}$ \\
\hline Do you refer to your teacher if you face problem? $\left(\mathrm{X}_{17}\right)$ & 0.1391 \\
\hline Teachers' performance $\left(\mathrm{X}_{18}\right)$ & $-0.2388^{*}$ \\
\hline Do the teachers Punish? $\left(\mathrm{X}_{19}\right)$ & 0.1476 \\
\hline How much do you spend on your tuition? $\left(\mathrm{X}_{20}\right)$ & -0.1221 \\
\hline Do you receive Mid-day Meal? $\left(\mathrm{X}_{21}\right)$ & $0.4898^{* * *}$ \\
\hline Food sufficiency $\left(\mathrm{X}_{22}\right)$ & $-0.4901^{* *}$ \\
\hline Quality of the Mid-day Meal $\left(\mathrm{X}_{23}\right)$ & $-0.5139^{* *}$ \\
\hline Washing hands $\left(\mathrm{X}_{24}\right)$ & $-0.4897^{* *}$ \\
\hline Does your school have toilet? $\left(\mathrm{X}_{25}\right)$ & -0.1406 \\
\hline Does anybody recite you stories? $\left(\mathrm{X}_{26}\right)$ & 0.1799 \\
\hline $\begin{array}{l}\text { Critical value }(2-\text { Tail, } 0.05)=+ \text { or }-0.197 \\
\text { Critical value }(2-\text { Tail, } 0.01)=+ \text { or }-0.256\end{array}$ & $\begin{array}{l}\text { ficant at } 5 \% \text { level } \\
\text { ificant at } 1 \% \text { level }\end{array}$ \\
\hline
\end{tabular}

\section{RESULT AND DISCUSSION}

Table I indicates that the results as above give the mean score and standard deviation score. According to the mean score and standard deviation, the medium high is in between 1.20 to 303.64. Data also showed that the mean score of item (How much do you spend on your tuition?) $\mathrm{X}_{20}, 303.64$ is the highest and standard deviation, 214.09. The lowest is item (Religion) $\mathrm{X}_{2}$, mean score 1.20 and standard deviation is 0.45 . Table II depicts that since $\mathrm{P}$ value is less than 0.01 , the null hypothesis is rejected at 1 percent level of significance. Hence it is 
concluded that there is significant relationship between dependent variable, the perception level of students on quality education at primary level (Y) and 26 casual variables.

Table III depicts the correlation analysis between dependent variable that is, the perception level of students on quality education at primary level (Y) and 26 casual variables. After doing the analysis it is found that only ten (10) casual variables have shown their level of significance towards addressing the perception level of students on quality education at primary level. It is found that Type of School $\left(\mathrm{X}_{1}\right)$ has a negative impact. Parents preferred private school to government school (Those under School Education Department and those under Panchayate and Rural Development i.e. Shishu Siksha Kendra) because in their perception the former is more capable of disseminating quality education. Due to their financial instability they are compelled to send their child to government schools. Parents perceive private schools with higher esteem because of the glaring difference in the number of teachers in both these types of schools. Religion $\left(\mathrm{X}_{2}\right)$ has shown positive results. It is noticed that the quality of education among Hindus is relatively better. Lesser Financial Stability $\left(\mathrm{X}_{4}\right)$ among the Muslims is the reason attributed to it and for that they tend to devote more time in generating income than in caring their child.

Problem in understanding text in school $\left(\mathrm{X}_{15}\right)$ is found to be positive. Students find it difficult to make out what they are taught in school. The reasons behind the problem in understanding text in school $\left(\mathrm{X}_{16}\right)$ are many such as most of the students are not familiar with Bengali letters; difficulty in understanding the English language as it is a foreign language and they are much scared of it; teachers are found to be more interested in teaching better students: so for not-so-better students it creates an invisible distance between them and their teachers and whenever the same teachers punish them this distance furthers. Consequently, these students are more reluctant to get their doubts cleared if any; this torn student-teacher relationship harms students in learning Mathematics. Sabuj Roy studies in class IV at Iswaripur Primary School in Kalyani Block. He is not so studious. He has been provided private tuition from his family. As his tutor Amar Sarkar is ill himself, he cannot teach him well. Even school is not a better place for him to study. He is not familiar with English letter and even most of the Bengali letters.

He is not even able to pronounce a word. He cannot write Bengali text. In mathematics he cannot solve basic level addition, subtraction, multiplication and division. There is a madam at school who teaches him well. Sabuj alleged that none of the male teachers teaches well. He and his friends receive corporal punishment. They are also asked to do some works of their teachers such as purchasing vegetables for Mid-day Meal, bringing Xerox copies of school documents, bringing tea and biscuits for teachers. Teachers' Performance (X18) has a negative impact. Apparently, in students' view even if most of the teachers differentiate between them based on their performance, it is found that inadequate number of teachers in most of the schools is more prominent reason behind this. As the Pupil to Teachers Ratio (PTR) is less than required, teachers are not able to handle disturbing students and likely to lose their temper. In most of the schools there is no class-wise teacher which is another constraint for teachers in imparting quality education.

Out of 100 students 81 go to government school where they are provided Mid-day Meal (MDM) and 19 go to private school where they are not provided Mid-day Meal (MDM). The proportion of students having Mid-day Meal $\left(\mathrm{X}_{21}\right)$ is positive at almost $90 \%$. Food sufficiency $\left(\mathrm{X}_{22}\right)$ is found to be negative. Students complain that they are not provided sufficient food and the cook carries home some portion of the meal allotted to them. Students from the most humble background often hesitate to ask for more food even if they are still hungry. Quality of the Mid-day Meal $\left(\mathrm{X}_{23}\right)$ provided is not of good quality, so the result is negative. The reason for it is inadequate funding for Mid-day Meal which is Rs. 4.48 per head with 100 gram rice. The finding of washing hands $\left(\mathrm{X}_{24}\right)$ before eating Mid-Day Meal is negative. Washing hands with soap is not frequent. Students are observed to have washed hands with clean water in most cases and with detergent in some instances. It is due to lack of awareness and government allocation for the same. If teachers are to allocate this they are to do this from the allocation for Mid-day Meal which is meagre at Rs.4.48 per head. In some instances teachers are found to have done it out of their own expenses and sometimes with the help of willing guardians but that cannot be a model to be imitated. Can this problem be left as it is or will the government take proper initiative in order to mend it?

Table IV shows the Multiple Regression Weight, " $\beta$ ” value and at the level at which " $t$ " value is significant. The table shows the relationship between relative contributions of 26 casual variables. 26 casual variables were significant at 0.05 levels significant at 5\% and 0.01 levels significant at $1 \%$ and the table also shows relationship of 26 casual variables toward the perception level of students on quality education at primary level (Y). From the values of the Beta (" $\beta$ ") value and "t" value for each variable, it is apparent that types of school and does any body recite you stories have the highest contribution. From above, the contribution of all the variables (26 casual variables) have a multiple correlation (R) of 0.72351and an adjusted $R$ square $\left(R^{2}\right)$ of 0.37097 . The combination of these variables explained standard error 2.4 per cent of the variance in the perception level of students on quality education at primary level as revealed by the coefficient determinant R2 (0.52347). From above shows the ANOVA of the effect of all the variables (26 casual variables) to predict in the perception level of students on quality education at primary level yielded a coefficient of multiple regression $\left(\mathrm{R}^{2}\right)$ of 52.35 per cent and adjusted $R$ square $\left(R^{2)}\right.$ of 0.37097 . The result indicate that analysis of variance of the multiple regression showed a significant F-ratio [F $(24,75)=3.43276]$. 
Table 4. Multiple Regression Analysis

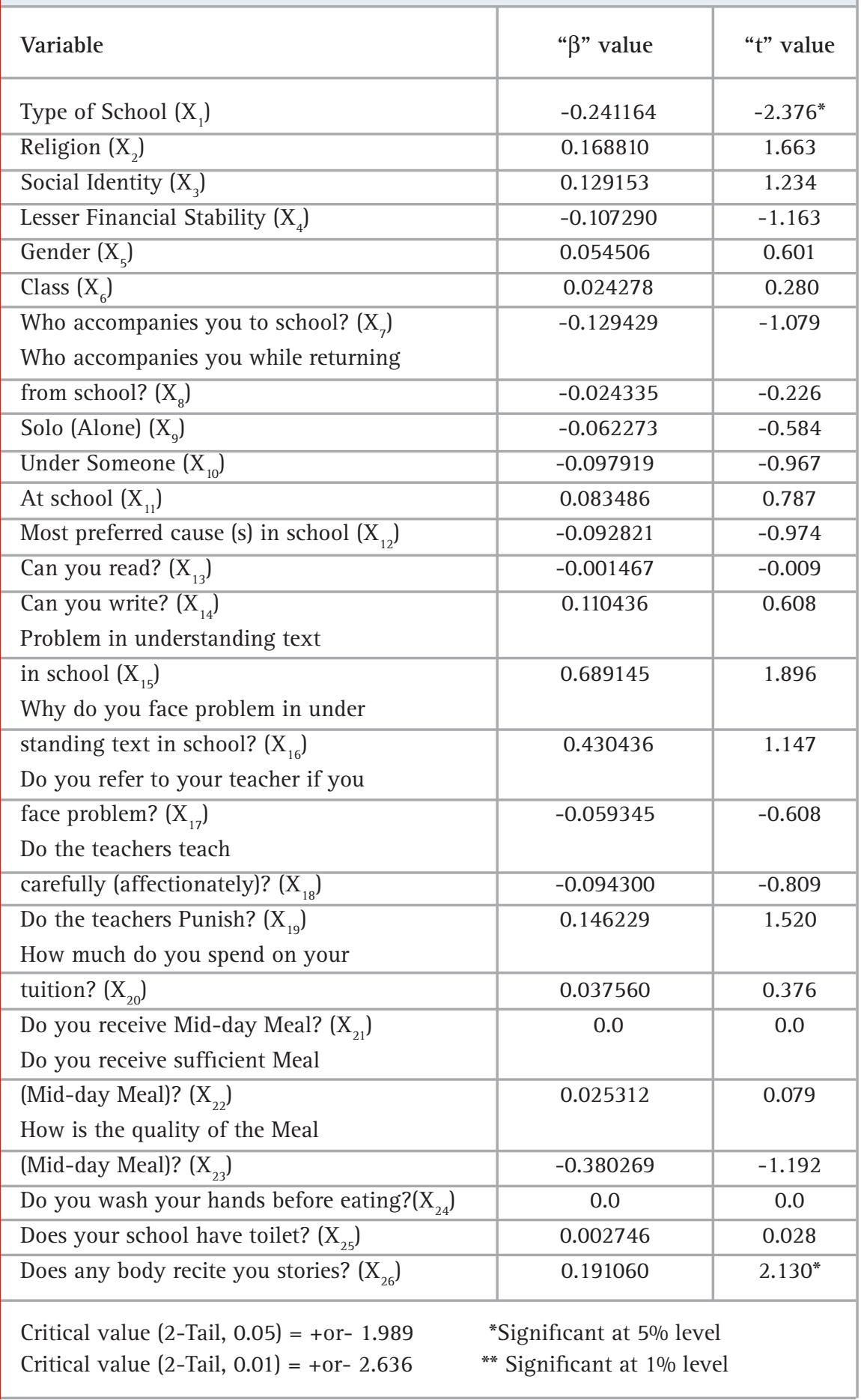

From the variables in table $\mathrm{V}$ to the regression model of regression analysis, it is found that after step 5, five variables are - Quality of MDM $\left(\mathrm{X}_{23}\right)$, Type of School based on school management (X1), Problem in understanding text in school $\left(\mathrm{X}_{15}\right)$, Religion $\left(\mathrm{X}_{2}\right)$, Does anybody recite you stories? $\left(\mathrm{X}_{26}\right)$ had explained 43.53 per cent of the total effect. Therefore, the remaining 21 variables explain only about 8.80 per cent of the total effect. Quality of the Mid-day Meal $\left(\mathrm{X}_{23}\right)$ provided, is not good. The reason for it is inadequate funding for Mid-day Meal which is
Rs. 4.48 per head with 100 gram rice. In the variable Type of School based on school management ( $\left.X_{1}\right)$, the state of the performance of students studying under the school education department is found to be relatively lower than that of their private school counterparts. Most of the students in government schools face problem in understanding their lessons $\left(\mathrm{X}_{15}\right)$. Regarding Religion $\left(\mathrm{X}_{2}\right)$, it is observed that the performance of the Hindu students is better when compared to the Muslim students. Among the Hindu students the 'Upper' caste students 
are far better and the Scheduled Caste students are still lagging behind. Within the Scheduled Caste students, children from the Namoshudra sub community have been performing well.

Table 5. Step-down Regression Model

\begin{tabular}{|c|c|}
\hline Step I = X23 & \\
\hline $\begin{array}{l}\text { Multiple R } \\
\text { R Square } \\
\text { Adjusted R Square } \\
\text { Standard Error }\end{array}$ & $\begin{array}{l}=0.51392 \\
=0.26411 \\
=0.25660 \\
=2.59923\end{array}$ \\
\hline $\begin{array}{l}\text { Step II = X1 } \\
\text { Multiple R } \\
\text { R Square } \\
\text { Adjusted R Square } \\
\text { Standard Error }\end{array}$ & $\begin{array}{l}=0.58214 \\
=0.33889 \\
=0.32526 \\
=2.47629\end{array}$ \\
\hline $\begin{array}{l}\text { Step III = X15 } \\
\text { Multiple R } \\
\text { R Square } \\
\text { Adjusted R Square } \\
\text { Standard Error }\end{array}$ & $\begin{array}{l}=0.61878 \\
=0.38289 \\
=0.36361 \\
=2.40490\end{array}$ \\
\hline $\begin{array}{l}\text { Step IV= X2 } \\
\text { Multiple R } \\
\text { R Square } \\
\text { Adjusted R Square } \\
\text { Standard Error }\end{array}$ & $\begin{array}{l}=0.61878 \\
=0.40789 \\
=0.38296 \\
=2.36805\end{array}$ \\
\hline $\begin{array}{l}\text { Step V= X26 } \\
\text { Multiple R } \\
\text { R Square } \\
\text { Adjusted R Square } \\
\text { Standard Error }\end{array}$ & $\begin{array}{l}=0.65975 \\
=0.43527 \\
=0.40523 \\
=2.32492\end{array}$ \\
\hline
\end{tabular}

It is owing to their being disciple of Sri Guruchand Thakur and Sri Harichand Thakur who gave education the most priority, used to appoint disciples based on their education culture who were required to have minimum materials for learning such as books, pen, paper etc. It is not that all the Muslim students are lagging behind, the better off among them have had their chances of getting quality education at various stages of time as the operation of Al-Ameen Mission is largely enclosed within the well offs presently. Although, the kind of community intervention mentioned above could bring substantial amount of development, the state intervention in this field is a must in order to bring about comprehensive development. Very few children are found to have been listening stories $\left(\mathrm{X}_{26}\right)$.

\section{Findings}

1. The quality of education, it is found is not, good enough. A guardian, Rupa Hazra of Kalyani Block has said, "Our children cannot be left uneducated only because we are illiterate". When she was asked why the quality of her children was not good, she replied, "How will our children get more education when we ourselves are uneducated?" "Teachers should not be blamed for this", she added.

2. Scheduled Tribes such as the Santhals and Scheduled caste such as the bind community who speak Bhojpuri face their biggest hurdle in alien language being used as the medium of instruction in school. Children come to make out Bengali almost after four years of schooling. By then, they are promoted to class three. But the Bhojpuri speakers cannot speak in Bengali even then. That is why they cannot interact with teachers and cannot get their doubts cleared. As they are basically poor in background they have to work many odd jobs to support their family. For instance, Laxmi Mahato, a class four student of Charjajira Primary school, Kanchrapara Gram Panchayate, Kalyani, carries stubble on her head along with her mother. Antara Biswas is also a class four student. She studies at Ishwaripur Kalitala Sishu Siksha Kendra. Along with studying she has to cook for her family and make blouse to support her family.

3. MDM has attracted a portion of students largely from among the poor. But it is allegedly complained by students and parents that they had been turned down when asked for adequate meal. The students further complained that the cook brought home much of their allocated food even if they were partly hungry. A reason attributed to this may be that the cook are often from 'higher castes' (Mahishya) and the mentioned students are from Scheduled Castes (Bauri).

4. Scholarships create eagerness among learners to perform better. However, not all the students get scholarships. In West Bengal only the students from minority communities are entitled to receive scholarships. This is a State provided discrimination.

5. The followings are some of the findings regarding educational status of students at primary level in Kalyani block:

A. While only $42.50 \%$ students in government schools can read Bengali, in private schools almost every student (above 90\%) can read Bengali.

B. $\quad 75 \%$ students in private schools can read as well as understand Bengali texts, while only 15\% of their counter parts in government schools can do the above.

C. There are $15 \%$ such students in government schools as are able to only read English texts. The percentage is 35 in private schools.

D. In government schools, only $6.25 \%$ students can read and make out English texts compared to 25\% of their peers in private schools.

E. Regarding mathematics, private school students are more advanced with $80 \%$ of them being able to do basic addition and subtraction than the 
government school students with only $44.25 \%$ students, solving basic addition and subtraction.

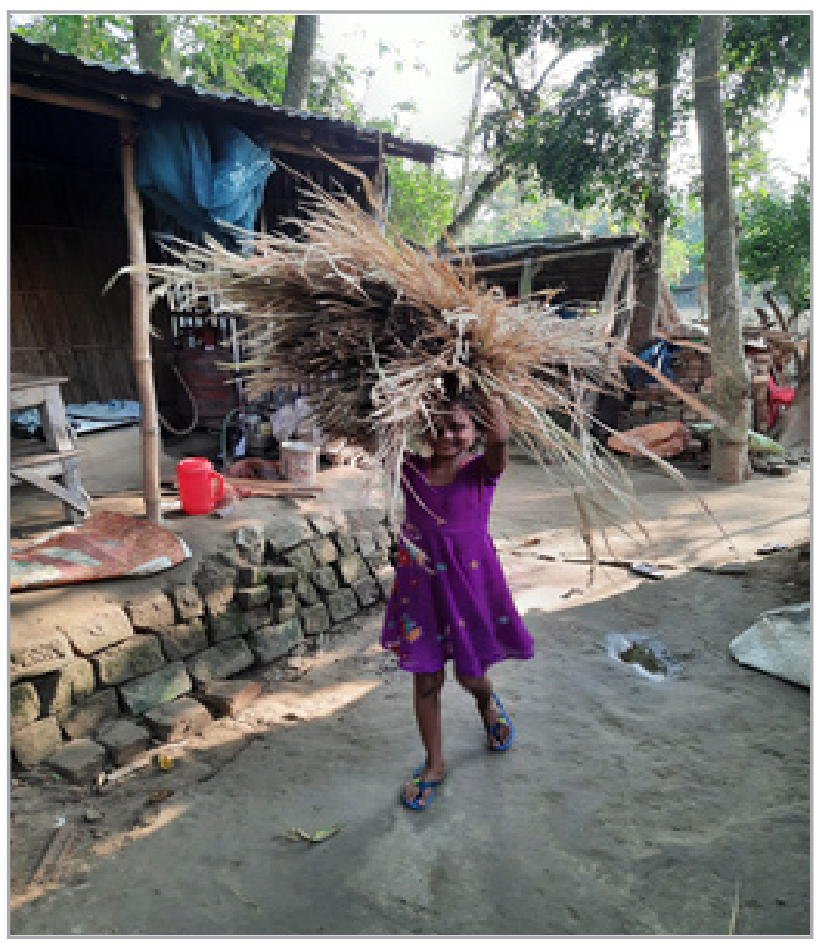

CONCLUSION

Nadia district of West Bengal has achieved the target of universalization of primary education. Now it is time to seek quality in education. According to most teachers it is necessary to have at least one teacher each class. Samagra Siksha Mission (SSM) District Information System for Education (DISE, 2018) data of Nadia district shows that Pupil Teacher Ratio is good at 1:22. But an inequality in distribution of teachers has been found to still prevail. In most schools the number of teachers stands at three, while in some schools, mostly in suburbs, the number of teachers is eight. On their part, the teachers complained of less salary. If their salary was increased, they could concentrate more on teaching rather than familial maters.

But this allegation of theirs is only partly true. Because the high school teachers receive a sizable pay packet but the quality of education among their learners remains inadequate. If truth be told, what lacks is genuine intention to teach students on part of the teachers. Additionally, it must be ensured that the students regularly attend school, MDM should be cooked well, communication among teachers and parents should take place on regular intervals so that the progress of the students can be discussed. Students can be drawn in by offering scholarships to all, not only minorities, like school dresses are offered.

\section{REFERENCES}

https://img.asercentre.org/docs/Publications/ASER\%20 Reports/ASER\%202016/aser_2016.pdf
Susanto, A. (2019). The Effect of Parental Guidance and Emotional Intelligence on Learning Achievement in Social Science. Journal of Family Sciences, Vol4-no2. Indonesia.

Lamar University. (2019). Correlation Between Parents' Education Level and Children's Success. Lamar University, https://degree.lamar.edu/articles/ undergraduate/parents-education-level-and-childrenssuccess/

Ntekane, A. (2018). PARENTAL INVOLVEMENT IN EDUCATION. See discussions, stats, and author profiles for this publication at: https://www.researchgate.net/ publication/324497851.

Bailey, T. (2017). The Impact of Parental Involvement on Student Success: School and Family Partnership From The Perspective of Students. Doctor of Education in Teacher Leadership Dissertations. 22. http:// digitalcommons.kennesaw.edu/teachleaddoc_etd/22.

Islam, A. (2017). Parental Involvement in Education: Evidence from Field Experiments in Developing Countries. Discussion paper, Department of economics, Monash Bussiness School, Issn no.-1441-5429.

Passiri, Y. (2017). Impact of Education and Parent Learning Effect on Student Learning Achievement of School Students Country Je'netallasa District Gowa. Journal of Business and Management (IOSR-JBM), e-ISSN: 2278-487X, p-ISSN: 2319-7668. Volume 19, Issue 6. Ver. IV (June 2017), Pp. 29-34

Mishra, A. (2016). Indian Heritage Parents' Strategies Of Parental Involvement In Support of Their Children's School And Non-School Learning In A Multicultural Context. The University of Leicester.

Johnson (Marozas), P. (2016). Types of Parental Involvement and Their Effect on Student Mathematics in Secondary Education: Attitudes, Self-Efficacy, and Achievement. from Starred Paper Committee: Hsueh-I Lo, Chairperson Ramon Serrano Sue Haller.

Parkash, J. [et al.]. (2016). A Study Of Parental School Involvement, Home Involvement \& Involvement Through Parents Teachers Association On Academic Achievement Of Primary School Student. International Journal of Current Innovation Research, Vol.2, Issue 04, Pp. 344-349.

Voicu, C. [Et.al.]. (2015). Parental Education for Childrens Rights. Procedia - Social and Behavioral Sciences, 191, pp.1707 - 1712. http://creativecommons.org/licenses/ by-nc-nd/4.0/

Reparaz, C. and Elizalde, M. A. S. (2015). Parental involvement in schools in Spain and Germany: Evidence from PISA 2015. International Journal of Educational Research, 93, pp.33-52. https://doi.org/10.1016/j. 
ijer.2018.10.001.

Chowa, G.A.N...[Et. al].(2013). Parental Involvement's Effects on Academic Performance: Evidence from the Youth Save Ghana Experiment. Center for social development Washington University in st. Louis, CSD Working Papers No. 13-15.

Drèze, j and Kingdon, G.G (2003) School Participation in Rural India, Review of Development Economics, Volume5, Issue 1, https://doi.org/10.1111/14679361.00103

Haldar A.M. (2016), Sri Sri Guruchand Charit, Sridham Thakur Nagar, printed: Modern Press, Thakur Nagar, Fifth Edition.

District Information System for School Education, 2018, Samagra Siksha Mission, Nadia. 